\title{
FINANCIAL STRATEGIES FOR MINIMIZING CORPORATE INCOME TAXES UNDER BRAZIL'S NEW GLOBAL TAX SYSTEM
}

\author{
Stephen T. Limberg \\ Visiting Professor, Fundação Getúlio Vargas. \\ Professor, The University of Texas, Austin. \\ E-mail: limberg@mail.utexas.edu \\ John R. Robison \\ Professor, The University of Texas, Austin.
}

Michael S. Schadewaid

Associate Professor, University of Wisconsin,

Milwaukee.

Stephen Limberg gratefully acknowledges the support of Philips do Brasil Ltda. without which this research would not have been possible. The authors also wish to express their appreciation for the valuable insights of $M r$. Raimundo L.M. Christians from Price Waterhouse in São Paulo, Brazil.

RESUMO: Em 1996, o Brasil adotou um sistema internacional de impostos de renda para empresas. Este sistema representa uma mudança fundamental em como o governo brasileiro trata as transações internacionais e as estratégias para minimizar os impostos para as empresas. Neste artigo, descrevemos as bases conceituais para um sistema internacional de impostos e o problema causado pela criação de uma dupla taxação. As reações do governo e da iniciativa privada à dupla taxação são consideradas. Também são analisados os mecanismos imperfeitos desenvolvidos no Brasil e em outros países para atenuação da taxação dupla. Finalmente, abordamos as estratégias utilizadas pelas empresas para não apenas evitar a dupla taxação como também ter as vantagens dos paraísos fiscais.

ABSTRACT: In 1996, Brazil adopted a worldwide income tax system for corporations. This system represents a fundamental change in how the Brazilian government treats multinational transactions and the tax minimizing strategies relevant to businesses. In this article, we describe the conceptual basis for worldwide tax systems and the problem of double taxation that they create. Responses to double taxation by both the governments and the private sector are considered. Namely, the imperfect mechanisms developed by Brazil and other countries for mitigating double taxation are analyzed. We ultimately focus on the strategies that companies utilize in order not only to avoid double taxation, but also to take advantage of tax havens.

PALAVRAS-CHAVE: estratégias financeiras, taxas de crédito estrangeiras, taxas internacionais, redução de impostos, sistema internacional de impostos de renda.

KEY WORDS: financial strategies, foreign tax credit, international tax, tax minimization, worldwide income taxes system. 
Brazilian trade policies and trends continue to indicate ongoing internationalization of its commercial markets. One such sign of Brazil's globalization is its recent adoption of a worldwide (or global) income tax system for corporations. Such a system is consistent with longstanding policies of most developed countries. The corporate strategic impact of this new system will become increasingly significant as Brazilian companies continue to look abroad. The purpose of this article is to describe the nature and challenges associated with a worldwide income tax system, and identify corporate strategies frequently undertaken to minimize an enterprise's global tax.

There is no global authority that establishes international : tax rules. The jurisdictional scheme that a country adopts: specifies the types of relationships with taxpayers that lawmakers believe are sufficient to justify taxation.

The first section develops the rationale underlying the global income tax system in Brazil, as well as other countries. Such a system often leads to the possibility that one dollar of earnings will be taxed by two or more jurisdictions, or so-called double taxed. The second section describes government responses to double taxation, including Brazil's response and that of other countries. Double taxation is of concern to governments because it might put their international businesses at a disadvantage in world markets. In the third section, we address the private sector's response to double taxation. By strategically managing global structures and finances, multinationals may not only mitigate double taxation, but also use tax havens to their advantage.

\section{JURISDICTION TO TAX}

At present, there is no global authority that establishes international tax rules. That is, there is no international tax law per se, only national tax laws. Therefore, each country has discretion over deciding who and what to tax. In this section, we discuss the type of connection used by countries to establish the right to tax.

What gives a country tax authority? The jurisdictional scheme that a country adopts specifies the types of relationships with taxpayers that lawmakers believe are sufficient to justify taxation. Typically, taxation in a country arises when a business entity is connected to the country in one of two ways namely, through a personal relationship or an economic relationship.

\section{Personal relationship}

A personal relationship with a country frequently leads to taxation. For individuals, such a personal relationship may be established by virtue of being a citizen or resident of a country. Corporations, the subject of this article, can also have a personal relationship with a country through citizenship or residency. A corporation is often considered a citizen of the country in which it is chartered. In some countries, mere incorporation is enough to establish tax authority, regardless of the company's activity level in the country of incorporation. Under the laws of other countries, incorporation does not, by itself, create tax authority. In those countries, some minimum level of activity is required before a government establishes its right to tax.

Virtually in all countries, corporate residency results in taxation. Residency typically depends on where a company is managed and controlled. Not surprisingly, the interpretation of terms such as "management" and "control" can take on different meanings in different jurisdictions. For example, one interpretation might be based on the location of board meetings whereas another interpretation might look to the location where day-to-day operations take place or the principal place where the business is located. Because definitions of residency vary with country, it is possible for a taxpayer to be a resident of two jurisdictions. To avoid this redundancy many tax treaties between countries have so-called tie breaker rules that determine a single residency location.

\section{Economic relationship}

An economic relationship with a country might also lead to taxation. For both individuals and companies, an economic relationship exists 


\begin{tabular}{|c|}
\hline $\begin{array}{l}\text { Before 1996, Brazil laxed the } \\
\text { income of corporations under } \\
\text { the ferriforial system of } \\
\text { taxation. Under this system, } \\
\text { only those corporations having } \\
\text { an economic relationship with } \\
\text { Brazil were toxed. That is, } \\
\text { Brazilian corporate cifizens } \\
\text { and residents were allowed to } \\
\text { exclude foreign sources' } \\
\text { income from domestic } \\
\text { taxation. Beginning in } 1996, \\
\text { Brazil began taxing the } \\
\text { income of Broxilion } \\
\text { corporations under } \\
\text { a worldwide tax system. }\end{array}$ \\
\hline
\end{tabular}

whenever they derive income from business activities or investment assets located within a country. Business activities usually create an economic relationship if a nontrivial part of the value added process occurs in a country, such as manufacturing, marketing, or distribution functions. Strict importing and nominal activities usually du not create an economic presence in a country. The set of entities deriving income from sources within a country includes not only citizens and residents (those persons who already have a personal relationship with the country), but also foreigners.

\section{Brazil's worldwide tax system}

Before 1996, Brazil taxed the income of corporations under the territorial system of taxation. Under this system, only those corporations having an economic relationship with Brazil were taxed. That is, Brazilian corporate citizens and residents were allowed to exclude foreign sources' income from domestic taxation. Under the territorial system, Brazil (the home country) asserted primary jurisdiction over domestic income whether the recipient of that income was a citizen, resident, or foreigner. Primary jurisdiction is the right to tax income irrespective of the jurisdictional claims of other countries. No jurisdiction was asserted over income derived from abroad.

Beginning in 1996, Brazil began taxing the income of Brazilian corporations under a worldwide tax system. In general, countries under this system impose tax based on both an economic and a personal relationship. Therefore, a foreign branch still has a personal relationship with the home country because it is merely a unit of the home company. Accordingly, a foreign branch's income will be taxed by the home country on the accrual basis, even if the income is not repatriated to the home office. On the other hand, a foreign subsidiary is a separate legal entity, hence it has no personal relationship with its parent's home country. Moreover, if it only earns income abroad, it has no economic relationship with its parent's home country. Accordingly, the income of a foreign subsidiary generally is not taxed at home until it is repatriated to the parent as, for example, dividends. The type of tax systems used by a sample of countries is shown in Exhibit 1.

\section{Exhibit 1}

Sample of Countries with Corporate Territorial versus Worldwide (WW) Tax Systems

\begin{tabular}{|ll|}
\hline \multicolumn{2}{|c|}{ Asia } \\
\hline Country & System \\
\hline Hong Kong & Territorial \\
Japan & $W W$ \\
Korea & $W W$ \\
Singapore & $W W$ \\
Thailand & $W W$ \\
\hline
\end{tabular}

\begin{tabular}{|ll|}
\hline \multicolumn{2}{|c|}{ Europe } \\
\hline Country & System \\
\hline France & Territorial \\
Germany & WW \\
Netherlands & WW \\
Poland & WW \\
U.K. & WW \\
\hline
\end{tabular}

\begin{tabular}{|c|c|c|c|}
\hline \multicolumn{2}{|c|}{ Latin America } & \multicolumn{2}{|c|}{ North America } \\
\hline Country & System & Country & System \\
\hline Argentina & WW & Canada & WW \\
\hline Brazil & WW & & WW \\
\hline Chile & WW & Mexico & WW \\
\hline Costa Rica & Territorial & & \\
\hline Venezuela & Territorial & & \\
\hline
\end{tabular}

As suggested by Exhibit 1, the worldwide tax system dominates among the world's largest trading countries. By adopting this system, Brazil joins the ranks of these countries. However, Brazil added a unique variation in its original enactment of a worldwide system. It not only accrues income from foreign branches, but it also accrues income from foreign subsidiaries. ${ }^{1}$ About six months after the enactment of this law another Brazilian tax pronouncement took a different position. It allowed taxation of a foreign
1. Law 9.249/95. Article 25. December 26, 1995 effective January 1, 1996. 
subsidiary's income based on the more traditional non-accrual approach, namely only when the income is repatriated. ${ }^{2}$ However, arguably this pronouncement does not carry the weight of law. Accordingly, as of this writing, it might be possible for taxpayers to operate under the law or the pronouncement creating an anomaly that is discussed later under the title "tax havens".

Under the worldwide tax system multinational corporations are likely to face international double taxation. A foreign branch's income is frequently taxed in the foreign country based on an economic relationship and the same income is taxed as accrued in the home country based on a personal relationship. Likewise, a foreign subsidiary's income is typically taxed abroad based on an economic and personal relationship with the foreign country. The same income is taxed when repatriated to the parent, and under Brazilian law it might even be taxed on the parent as accrued.

As a result, a fundamental issue faced by governments using a worldwide tax system is how to mitigate international double taxation. Both the home and the host countries must decide whether and how to adjust their tax system when there are competing jurisdictional claims. Commonly, double taxation is mitigated by countries acting alone (unilaterally) and, in some cases, they act together (bilaterally) through tax treaties.

\section{GOVERNMENT RESPONSE TO DOUBLE TAXATION}

\section{Unilateral mechanisms}

2. Instrução Normativa 38 . Article 2, Section 1. June 28, 1996.

3. $\$ 40=\$ 60$ foreign source income $-\$ 20$ foreign taxes paid

4. The limited, as well as unlimited, FTC systems typically provide a credit only for foreign direct taxes, namely income taxes. Because they provide no relief for foreign indirect taxes, for example value added taxes, they are bias against foreign investments in countries with large indirect taxes. assume a company pays $\$ 20$ in foreign taxes on $\$ 60$ of a foreign branch's earnings. When the $\$ 60$ of foreign earnings is considered as taxable income back home, a $\$ 20$ deduction for foreign taxes paid still results in a home tax base of $\$ 40^{3}$ from foreign income. In other words, $\$ 40$ is still double taxed. For this reason, countries usually do not rely exclusively on this deduction mechanism.

Another worldwide mechanism by which a home country can mitigate double taxation is to include all their home and foreign income in the tax base, but allow an unlimited foreign tax credit (FTC), or domestic tax offset, equal to the foreign income taxes paid. If the FTC is unlimited, foreign income taxes paid offset the home country income tax, even if the host country tax rate exceeds that of the home country. The home country still asserts primary tax jurisdiction over domestic corporate income, but only secondary jurisdiction over the foreign income. The claim is secondary in the sense that the home country forgoes the right to collect taxes to the extent the corporation's foreign income is taxed by the host country. However, because foreign taxes in excess of home taxes (on foreign income) offset taxes on domestic income, this method is not adopted by countries very frequently.

Brazil, like most countries using a worldwide tax system, has adopted a limited FTC. Like the unlimited FTC, the mechanics of a limited FTC can be complicated. However, the following conceptual interpretation is sufficient to capture critical aspects of the limited FTC. In essence, if the home tax rate is greater than the foreign tax rate, the FTC equals the foreign taxes paid. This is no different than the unlimited FTC. However, if the home tax rate is less than the foreign rate, the FTC is limited to the domestic tax on the foreign income. Therefore, conceptually this credit is the lesser between (a) the foreign taxes paid or (b) the domestic taxes on the foreign source's income. ${ }^{4}$ Application of this concept is illustrated below.

- Base case - no FTC. Assume, for example, that $\mathrm{Bco}$ is a Brazilian corporation with a foreign branch in country F. For simplicity assume Bco's annual taxable income is $\$ 100$, of which $\$ 40$ is earned in Brazil and $\$ 60$ in F. Brazil's corporate income tax rate is 25 percent, and F's rate is 35 percent. Brazil 
and $\mathrm{F}$ use the same rules for computing and sourcing taxable income. ${ }^{5}$

If Brazil provides no mechanism for mitigating double taxation, then the full amount of Bco's foreign income may be taxed by both Brazil and $\mathrm{F}$, as follows.

\begin{tabular}{|c|c|}
\hline Bco's Brazilian Tax Relurn & Bco's Couniry F Tax Return \\
\hline F source income $\quad \$ 60$ & F source income $\quad \$ 60$ \\
\hline+ Brazilian income & + Brazilian income \\
\hline$=$ Taxable income $\quad \$ 100$ & $=$ Taxable income $\quad \$ 60$ \\
\hline$\times$ Tax rate $\quad 25 \%$ & $x$ Tax rate \\
\hline$=$ Brazilian tax $\quad \$ 25$ & $=F \operatorname{tax}$ \\
\hline na $=$ not applicable & \\
\hline
\end{tabular}

Taxations in Brazil and $\mathrm{F}$ combine for a total tax of $\$ 46^{6}$ on Bco's earnings of $\$ 100$, for an overall tax rate of 46 percent. $^{7}$ Bco's foreign source's income of $\$ 60$ is double taxed, resulting in a total tax rate of 60 percent $^{8}$ on this income. The following subsections illustrate the concept underlying the limited FTC mechanism Brazil and many other countries use to mitigate this double tax.

- Excess credit case. By allowing a FTC for foreign taxes that is limited to the domestic tax on foreign income, Brazil eliminates Bco's double tax in the base case. Applying the concept above, this credit is the lesser between (a) $\$ 21$ of $F$ taxes paid or (b) $\$ 15^{9}$ of Brazilian pre-FTC tax on F income. As shown below, the resulting $\$ 15$ FTC leaves Bco with a domestic tax liability of $\$ 10$, which represents the Brazilian tax on Bco's $\$ 40$ in Brazilian income.

\section{Bco's Brazilian Tax Return Bco's Country F Tax Return}

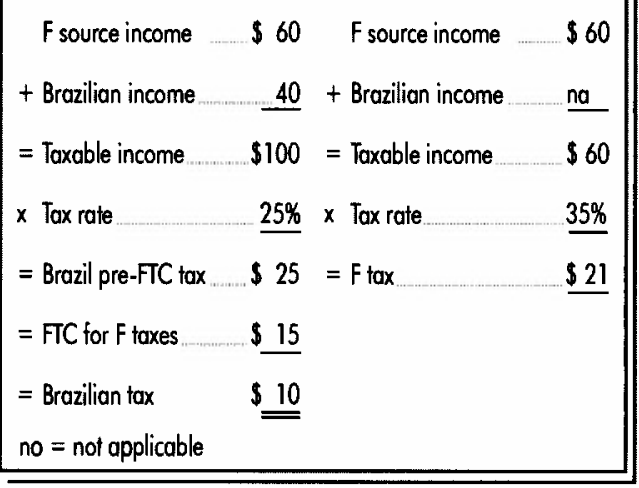

Taxation in Brazil and $\mathrm{F}$ combine for a total tax of only $\$ 31^{10}$ on Bco's earnings of $\$ 100$, hence an overall tax rate of 31 percent. ${ }^{11}$ Bco's foreign income of $\$ 60$ is taxed only once, albeit at the higher foreign rate of 35 percent. The $\$ 6$ difference between the $\$ 21$ paid to $\mathrm{F}$ and the $\$ 15 \mathrm{FTC}$ allowed is called an excess credit. It represents a foreign tax cost for which Bco received no benefit on its Brazilian tax return.

- Short credit case. Assume now that Bco's branch is in country $L$ where the tax rate is only 15 percent. The following worldwide taxes result.

\begin{tabular}{|lrrr|}
\hline Bco's Brazilian Tax Return & Bco's Country L Tax Return \\
\hline L source income & $\$ 60$ & L source income & $\$ 60$ \\
+ Brazilian income & $\underline{40}+$ Brazilian income & $\underline{\text { na }}$ \\
$=$ Taxable income & $\$ 100$ & $=$ Taxable income & $\$ 60$ \\
$\times$ Tax rate & $\underline{25 \%} \times$ Tax rate & $\underline{15 \%}$ \\
$=$ Brazil pre-FTC tax & $\$ 25$ & $=$ L tax & $\$ 9$ \\
- FTC for L tax & $\$ 9$ & \\
$=$ Brazilian tax & $\$ 16$ \\
na $=$ not applicable
\end{tabular}

Taxation in Brazil and L combine for a total tax of only $\$ 25^{12}$ on Bco's earnings of $\$ 100$ and an overall tax rate of 25 percent. $^{13}$ In essence, Brazil allows Bco to reduce its $\$ 15^{14}$ domestic tax on $\mathrm{L}$ source's income taking into account the $\$ 9$ already paid to $L$. The resulting $\$ 6^{15}$ difference paid to Brazil is referred to as a short credit because Bco is short of, namely lacks, $\$ 6$ paid as foreign taxes, that could be used to offset domestic taxes on the foreign source's income.

- Cross crediting. Excess credits represent a potential tax savings in the home country. Therefore, companies frequently manage their excess credits to derive full benefit from them. An effective strategy for managing excess credits is to combine them with short credits. This may be possible if a company operates in at least two foreign countries, one with an income tax rate above the home country's rate and the other with a rate below. For example, the following tax results if Bco derives half $(\$ 30)$ its foreign source's income from country $F$ and the other half $(\$ 30)$ from country $L$.
5. This assumption simplifies the analysis but may be invalid in many instances since there are often numerous differences between how two countries define and source taxable income.

6. $\$ 46=\$ 25$ Brazilian tax paid $+\$ 21$ $F$ tax paid.

$7.46 \%=\$ 46$ worldwide taxes paid $\$ 100$ worldwide income.

8. $60 \%=35 \% \mathrm{~F}$ tax rate $+25 \%$ Brazilian tax rate.

9. $\$ 15=25 \%$ Brazilian tax rate $\times \$ 60$ $F$ source income.

10. $\$ 31=\$ 10$ Brazilain tax paid + $\$ 21 \mathrm{~F}$ tax paid.

11. $31 \%=\$ 31$ worldwide tax paid $/$ $\$ 100$ worldwide income.

12. $\$ 25=\$ 16$ Brazilian tax paid $+\$ 9$ $L$ tax paid.

$13.25 \%=\$ 25$ worldwide tax paid / $\$ 100$ worldwide income.

14. $\$ 15=\$ 60$ L source income $\times 25 \%$ Brazilian tax rate.

15. $\$ 6=\$ 15$ Brazilian tax paid $-\$ 9$ FTC. 


\begin{tabular}{|c|c|c|}
\hline Bco's Brazilian Tax Return & Bco's Country F Tax Return & Bco's Country L Tax Return \\
\hline L source income $\quad \$ 60$ & F source income $\quad \$ 30$ & L source income \\
\hline + Brazilian income & + Brazilian income na & + Brazilian income \\
\hline$=$ Taxable income & $=$ Taxable income $\quad \$ 30$ & $=$ Taxable income $\quad \$ 30$ \\
\hline$x$ Tax rate & $\times$ Tax rate & $x$ Tax rate \\
\hline$=$ Brazil pre-FTC tax $\$ 25$ & $=F \operatorname{tax}$ & $=\mathrm{L} \operatorname{tax}$ \\
\hline FTC for $F \& L$ taxes $\$ 15$ & & \\
\hline $\begin{array}{l}=\text { Brazilian tax } \\
\text { na = not applicable }\end{array}$ & & \\
\hline
\end{tabular}

16. $\$ 25=\$ 10$ Brazilian tax paid + $\$ 10.5 \mathrm{~F}$ tax paid $+\$ 4.5 \mathrm{~L}$ tax paid.

17. $25 \%=\$ 25$ worldwide tax paid $/$ $\$ 100$ worldwide income.

18. $\$ 15=\$ 10.5 \mathrm{~F}$ tax paid $+\$ 4.5 \mathrm{~L}$ tax paid.

19. $\$ 15=\$ 60$ foreign $(F+L)$ source income $+25 \%$ Brazilian tax rate.

$20.25 \%=(\$ 10.5 \mathrm{~F}$ tax paid $+\$ 4.5 \mathrm{~L}$ tax paid) $/ \$ 60$ foreign $(F+L)$ source income.
Bco's tax is only $\$ 25^{16}$ on worldwide earnings of $\$ 100$. This is less than the $\$ 31$ worldwide tax when all $\$ 60$ of Bco's foreign earnings were from $F$ (excess credit case), and equal to the worldwide tax when all of Bco's foreign earnings derived from $\mathrm{L}$ (short credit case). In other words, Bco can operate in $\mathrm{F}$ and still enjoy an overall tax rate of only $25 \%{ }^{17}$ even though the tax rate in $\mathrm{F}$ is $35 \%$.

What enables this outcome? Recall that conceptually the FTC is the lesser between (a) the $\$ 15^{18}$ foreign tax paid or (b) the $\$ 15^{19}$ domestic tax on the foreign source income. In either case the FTC is $\$ 15$. By combining the taxes paid in $\mathrm{F}$ and $\mathrm{L}$ the average foreign $\operatorname{tax}$ rate is 25 percent, ${ }^{20}$ or equal to the domestic tax rate on foreign income. In essence, cross crediting allows companies to use a weighted average foreign tax rate while computing foreign taxes. In this case, this average rate is equal to the domestic rate. Therefore, the entire domestic tax on foreign income is offset by the FTC.

To prevent this type of cross crediting some countries, such as the United Kingdom, apply a so-called country-by-country FTC limitation, which prevents the taxes paid in one foreign country to be combined with those of another foreign country. Under this system, cross crediting can still apply within a country if different tax rates apply to different types of income, such as operating income and interest income. Other countries, such as the United States of America, allow taxes paid across countries to be combined, but only for separate classes, or baskets, of income. For example, taxes paid across countries can be combined for operating income, but this basket of taxes must be kept separate from taxes paid on passive income, such as interest and dividend income. At the present time, Brazil has neither a country-by-country or income basket limitation.

The cases above are based on the operation of foreign branches. However, international activities are commonly undertaken through foreign subsidiaries. In this case, a foreign source's income typically is only taxed when repatriated, for example through dividends paid to the domestic parent. The principles illustrated above still apply, but with an extra degree of flexibility. Namely, the parent can decide when dividends will be paid, hence when foreign earnings are subject to domestic taxes. Effective cross crediting strategies should balance the timing and amount of foreign dividends to minimize excess taxes, thereby minimizing taxes. For example, assume the foreign entities in the cross crediting example above are foreign subsidiaries of Bco instead of foreign branches. Bco's tax minimizing strategy is to pay equivalent dividends from $\mathrm{F}$ and $\mathrm{L}$ in the same year leading to the same result illustrated above.

\section{Bilateral mechanisms}

Territorial systems, or deductions and/or FTCs under worldwide tax systems represent unilateral solutions to international double taxation in the sense that they are created by individual countries (and multilateral solutions in the sense that they apply to outbound transactions involving any foreign country). As another means of preventing international double taxation, countries also enter into bilateral tax treaties only applicable to the two countries that are party to the agreement.

Tax treaties contain provisions that reduce the tax imposed on income derived by corporate (and individual) citizens of one treaty country from sources within the other treaty country. For example, country A may agree to forgo the tax on dividend income derived from within its borders by citizens of country B in exchange for the reciprocal treatment by country $B$. The effect of such treaty provisions is to give the home country primary tax jurisdiction. This is just the opposite effect of unilateral techniques in which the home country usually relinquishes primary tax jurisdiction. 
Therefore, under treaties a larger share of the tax on international transactions is saved for the home country by subordinating jurisdictional claims based on economic relationships to claims based on personal relationships. Of course, the increase in the home country's tax revenues comes at the host country's expense. As a consequence, tax treaty provisions are uniformly reciprocal in nature.

The shifting of primary jurisdiction to the home country also explains why tax treaties frequently do not exist between developed and developing countries. Developing countries often play host to foreign investment. They do not want to relinquish their right to tax these investments by shifting their primary jurisdiction to the (foreign) home country as would occur under conventional treaties. This is especially true because, with limited outbound investment, developing countries gain little by the reciprocal provisions in treaties.

Treaties are crafted to meet the specific objectives of the negotiating countries. One prototype document for starting treaty negotiations is the 1994 model treaty of the Organization for Economic Co-operation and Development (OECD). ${ }^{21}$ Forerunners of this influential model treaty are the 1992, 1977 and 1963 OECD model treaties, and 1921 studies by the League of Nations, (the OECD antecessor) that culminated in the first model treaty.

In 1980, the United Nations (UN) also developed a model treaty most distinguished for supporting tax authority based on income source, namely economic relationships. The UN treaty is frequently the starting point for negotiations to many Latin American countries including Brazil. This is because it acknowledges the tax rights of developing countries over income derived from them by richer capital exporting countries.

For example, the UN model treaty increases the likelihood that a business will be considered to have a so-called permanent establishment in another country. In essence, a permanent establishment is the term used to describe the level of economic activity in a host country that justifies taxation by the host country. ${ }^{22}$ For example, to create a permanent establishment associated with a building site and consultant services, 12 months of activity are required under the 1994
OECD treaty, but only six months are required under the 1980 UN treaty. Accordingly, a foreign building contractor in Brazil would be subject to Brazilian taxes after only six months of activity under the UN model, whereas under the OECD model 12 months of activity are required. It is no wonder the UN model is preferred. Likewise, whereas maintaining inventory for delivery and having independent agents in a foreign country do not constitute a permanent establishment under the 1994 OECD treaty, they do under the 1980 UN treaty.

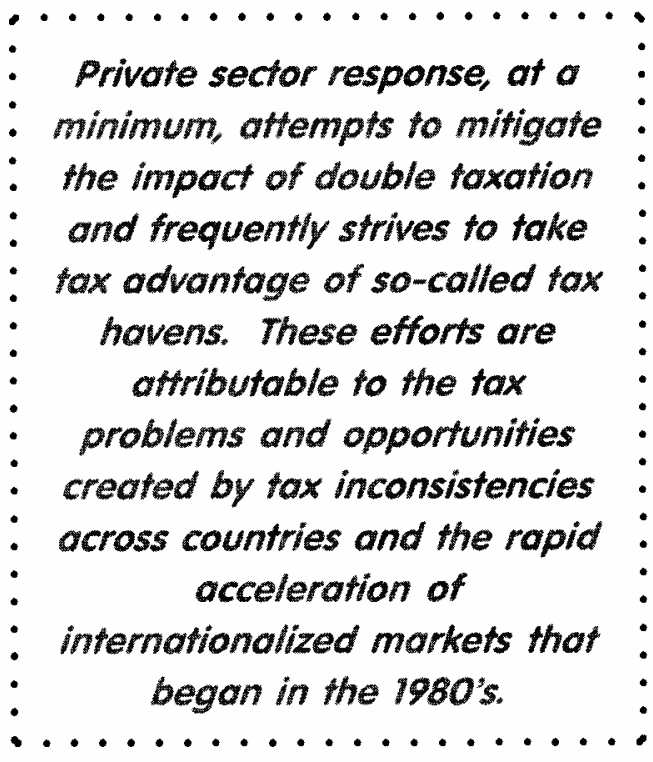

In theory, the slightest economic relationship with a host country is enough to create the right for that country to impose taxation. By exempting nominal economic activities from host country taxation, permanent establishment provisions facilitate administration and reduce trade inhibiting regulation.

\section{COMPANY RESPONSE TO DOUBLE TAXATION ${ }^{23}$}

Private sector response, at a minimum, attempts to mitigate the impact of double taxation and frequently strives to take tax advantage of so-called tax havens. These efforts are attributable to the tax problems and opportunities created by tax inconsistencies across countries and the rapid acceleration of internationalized markets that began in the 1980's.
21. OECD COMMITTEE ON FISCAL AFFAIRS. Model tax convention on income and capital. Article 9(1). OECD publication service, March 1994.

22. More specifically, the OECD treaty indicates that a permanent establishment includes a place of management, a branch, an office, a factory, a workshop, and natural resource extraction facilities. A permanent establishment does not include a foreign enterprise's use of a facility solely for the purpose of storage, display, or delivery of goods; maintenance of a stock solely for storage display, delivery or processing; maintenance of a fixed place of business solely for purchasing goods collecting information, preparatory or auxiliary activities or a combination of all these items so long as the activity is of a preparatory or auxiliary character. OECD COMMITTEE ON FISCAL AFFAIRS. Model tax convention on income and capital. , Article 5(2),(3) and (4). OECD publication service, March 1994.

23. For a more detailed discussion of selected concepts in this section see OGLEY, A. The Principles of International Tax: A Multinational Perspective. Interfisc Publishing, 1995 


\section{Mitigating double taxation}

- Avoid connection. An obvious method companies might use to mitigate double taxation is to avoid a connection altogether with a host country. For example, acting at a level of business below that of a permanent establishment is one approach in order to avoid such a connection. Another, more complex mechanism applies when there is cross-boarder ownership of a multinational enterprise as shown in Exhibit 2.

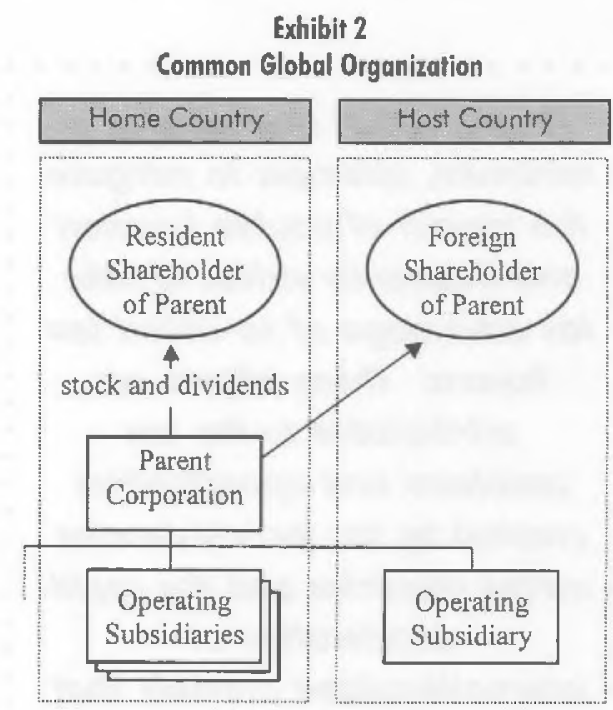

A foreign investor in a host country may have direct ownership in, hence receive dividends from, a parent corporation in the home country. At the same time, the parent may be deriving a substantial amount of its profit from an operating subsidiary in the host country. The structure shown in Exhibit 2 can be modified to minimize the number of jurisdictions through which dividends pass. Such a modification often strives to accomplish at least two objectives. First, it endeavors to give foreign shareholders direct access to profits generated by subsidiaries located in their countries. Even if subsidiaries and foreign shareholders are in different tax jurisdictions, it may seek to by-pass the parent corporation if it adds an extra tax jurisdiction. Second, these structures attempt to maintain management continuity and ownership control through the parent. In general, those strategies modify Exhibit 2 so it appears as in Exhibit 3.

As shown in Exhibit 3, a structure that
Exhiblt 3

Restructured Global Organization

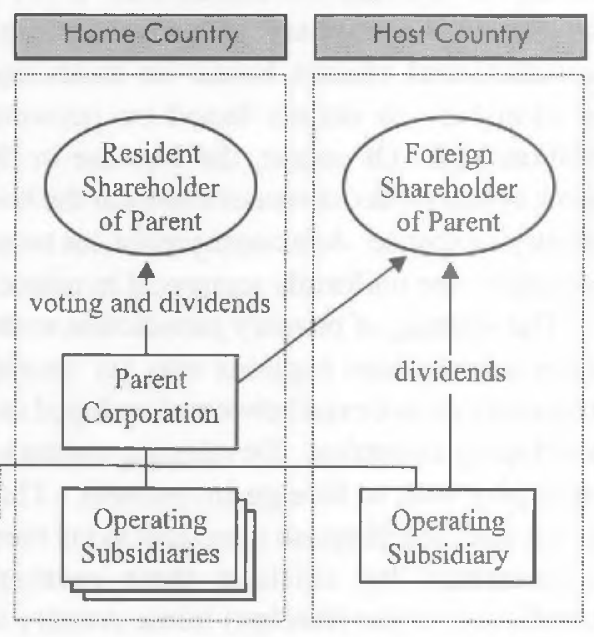

results in some form of direct ownership of a foreign subsidiary by foreign shareholders may keep dividend payments in one jurisdiction. The specific approaches taken to accomplish this outcome involve so-called stapled stocks, income or dividend access schemes, and other related schemes that are broadly labeled as hybrid structures. The tax advantages of these strategies must be weighed against their possible disadvantages which include potential complexity, anti-avoidance measures that governments may enact, and potential increased risk to shareholders that may result in discounted stock values.

A stapled stock structure requires a foreign shareholder to own shares in two companies that are traded together. The foreign shareholders' dividends are likely to flow from only one of the two companies, preferably the company that is located in the shareholders' jurisdiction or a jurisdiction that has favorable tax agreements with the shareholders' jurisdiction. The Nestle group depicted in Exhibit 4 reflects a well known example of the stapled stock structure.

Unilac equity issued two types of stock, namely founders' shares and (dividend) bearer shares. Only founders' shares had voting rights and they were owned in trust. Nestle controlled Unilac as a beneficiary of the trust, and through representation on the Unilac board of directors. This provided control and management continuity for the group. Panamanian shareholders owned Unilac bearer shares which had beneficial rights to dividends 


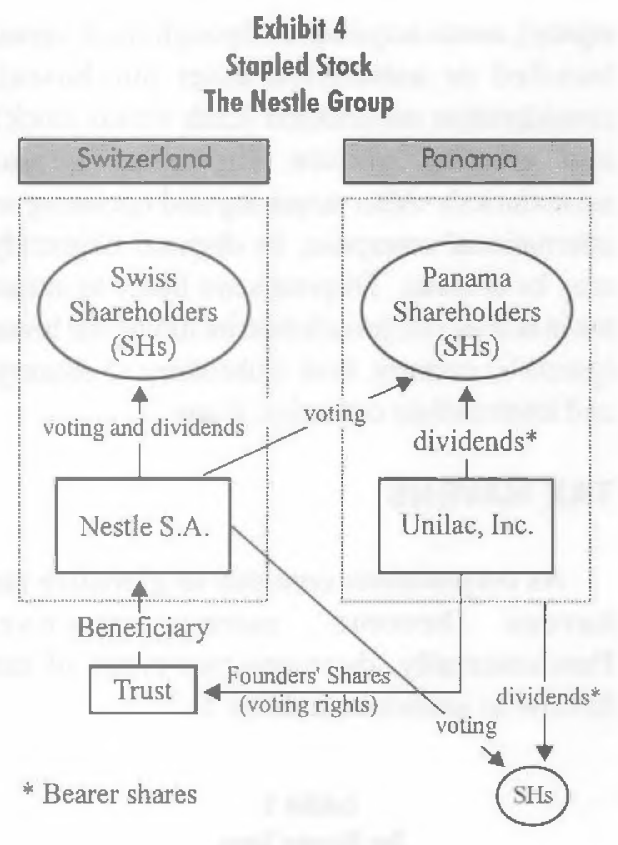

and distributions in liquidation (no voting rights), but only if they were held and traded concurrently with Nestle voting shares, bearing the same serial number. Through this structure Unilac shareholders were able to receive dividends directly, instead of through Nestle, and at the same time continue to have a vote in Nestle. Shareholders who were neither Swiss or Panamanian could still benefit from holding bearer shares to the extent that profits earned in, and dividends earned from, Panama were more favorably treated than those from Switzerland.

Income and dividend access schemes grant foreign shareholders of the parent corporation rights to receive profits directly from a foreign subsidiary. As with stapled stock strategies, preferably the subsidiary is located in the foreign shareholders' jurisdiction. One mechanism for achieving this outcome is to see that income access shares of the foreign subsidiary are issued to the foreign shareholders residing in the subsidiary's jurisdiction. These shares are simply income rights, and may or may not be stapled to shares of the parent. Alternatively, a trust may be established to hold income access shares. The foreign shareholders may be named as trust beneficiaries, and they may elect to receive dividends from the foreign subsidiary in lieu of dividends from the parent.

Hybrid structures is a catch-all term capturing all other schemes that attempt to minimize the number of jurisdictions through which dividends flow. For example, dividend and liquidation rights in foreign subsidiaries might be held by residents of the foreign jurisdiction while voting power is held by the parent directly or indirectly through a holding company. Alternatively, companies in different jurisdictions might be completely held by local citizens, but bound together by a so-called equalization agreement. Under this type of ownership, a reciprocal agreement requires that the two companies must pay equal dividends and equal distributions upon liquidation.

- Divert or extract profits. If a company is economically connected to a host country, taxable profits may be diverted away from the host jurisdiction. More specifically, taxes may be minimized in a host country by minimizing taxable profits through intercompany transfer pricing on goods, services and rights. For example, a company subject to high taxes can charge a low price for goods transferred to a related company in a low tax country. The low price will minimize taxable income, hence taxes, for the selling company. Of course, a multitude of nontax considerations may also dictate transfer prices, such as the impact of the related party's transfer prices on cash flows, bonus-based compensation, market penetration strategies, duties, anti-dumping rules, and exchange controls. In addition, government's have increasingly enacted and enforced regulations that restrict transfer prices between related entities. ${ }^{24}$

When profits cannot be diverted through transfer pricing of goods, the focus turns to extracting profits in other tax deductible ways. For example, a parent may capitalize its highly taxed foreign subsidiary with debt. Accordingly, profit extraction can take the form of tax deductible interest payments to the parent by the subsidiary, thus reducing the subsidiary's taxable income and taxes. However, excessive debt capitalization may be challenged by taxing authorities.

Other forms of tax deductible payments from host country subsidiaries may include royalties, rents, service fees, and insurance premiums, to name a few. Proper valuation of these deductible transfers still falls under the purview of transfer pricing. Moreover, companies must be aware that payments of items such as interest and royalties (as well as
24. See, for example, LIMBERG S.T., ROBINSON J.R. and CHRISTIANS, R.L.M. International Transfer Pricing Strategies for Minimizing Global income Taxes. Working paper, Fundaçāo Getúlio Vargas, Sāo Paulo, Brazil. November 1996; and LIMBERG, S.T., ROBINSON J.R. and CHRISTIANS, R.L.M. International Transfer Pricing Restrictions: Impact on Corporale Financial Policy. Working paper, Fundação Getúlio Vargas, São Paulo, Brazis. November 1996. 
dividends) may be subjected to so-called withholding taxes by the country of disbursement. Withholding taxes are charged on payments such as those when they leave the host country. Bilateral tax treaties reduce or eliminate withholding taxes between treaty countries. Therefore, an extensive network of bilateral treaties may be a valuable tax planning tool.

- Distributions. If multiple jurisdictions cannot be avoided and profits cannot be diverted or extracted then distributions from host jurisdictions may be considered when feasible. Tax benefits from distributions arise if taxes are lower in the home country, hence enabling a higher after-tax return on future earnings. Tax costs associated with distributions include withholding taxes and income taxes in the distributee's country.

Withholding taxes are frequently minimized by so-called treaty shopping. That is, if withholding tax rates are high between a parent and foreign subsidiary, the subsidiary may be owned by a holding company in an intermediate country that has low treaty withholding rates. Taxes may be minimized on distributions to the holding company. A low treaty withholding rate between the intermediate country and the parent's country may enable the funds to finally be distributed to the parent at a favorable withholding tax rate. Alternatively, the funds may be parked, or left, in an intermediate country. As will be more discussed in the next section, this has special appeal if the intemediate country is a tax haven in which no or low taxes apply to earnings within the country.

Of course, a number of nontax factors will also influence distribution decisions, such as the subsidiary's need for reserves, and political and exchange risks associated with retaining profits in the subsidiary. In addition, countries are increasingly adopting anti-treaty shopping provisions in their bilateral agreements. For example, the OECD model treaty requires that favorable treaty withholding rates will not apply unless the recipient of dividends, interest and royalties, is also the beneficiary owner, rather than just an intermediary. ${ }^{25}$

- Acquisitions and Disposals. Successful 25. OECD COMMITTEE ON FISCAL AFFAIRS. Model tax convention on income and capital. Articles 10(4), 11(4), and 12(3). OECD publication service, March 1994. equity), assets acquisition (through stock versus bundled or unbundled asset purchases), consideration surrendered (cash versus stock), and entities chosen (branches versus subsidiaries). After acquiring and operating an international enterprise its disposal ultimately may be at issue. Disposals are likely to attract tax in at least one jurisdiction including the home (parent's) country, host (subsidiary's) country, and intermediate countries, if any.

\section{TAX HAVENS}

As corporations continue to globalize tax havens become more attractive. Fundamentally, there are two types of tax havens as shown in Exhibit 5.

Exhibit 5

Tax Havens Types

\begin{tabular}{|c|c|c|}
\hline Type & Tax Treaties & Examples \\
\hline $\begin{array}{c}\text { No or } \\
\text { low tax }\end{array}$ & $\begin{array}{c}\text { No or } \\
\text { limited } \\
\text { treaties }\end{array}$ & $\begin{array}{c}\text { Jersey, Madeira Island } \\
\text { Bermuda, } \\
\text { Caymans Islands, } \\
\text { Netherlands Antilles, } \\
\text { and Cook Islands }\end{array}$ \\
\hline $\begin{array}{c}\text { Normal tax } \\
\text { with } \\
\text { preferences }\end{array}$ & $\begin{array}{c}\text { Treaiy } \\
\text { network }\end{array}$ & $\begin{array}{c}\text { Hong Kong, Ireland, } \\
\text { Luxembourg, Netherlands, } \\
\text { Singapore, and } \\
\text { Switzerland }\end{array}$ \\
\hline
\end{tabular}

One type of tax haven is characterized by no or low taxes. Recall that tax treaties usually contain a reciprocal agreement under which a host country surrenders various rights to the tax treaty partner companies. Because this type of tax haven has no or low taxes to surrender, it has little to offer a potential treaty partner. Accordingly, these countries typically have a low or limited network of international tax treaties. However, there are notable exceptions. For example, many countries that have a tax treaty with the Netherlands have extended it to the Netherlands Antilles, a part of the Netherlands Kingdom. Similarly, treaties with Portugal include its territory of Madeira Island which has no income taxes.

A second type of tax haven has normal taxes, but with significant preferences. For example, manufacturers receive substantial tax preferences if they are located in Ireland. Further, Dutch domestic tax law excludes taxes on dividend income, capital gains, and income from overseas branchs. Moreover, there is no

$$
\text { Us }
$$

RAE - v. 37 - n. 1 - Jan./Mar. 1997 
withholding tax on royalties or interests, and dividend withholding taxes are low. Because tax haven countries of this type have a normal tax systems, albeit with preferences, they frequently have an extensive network of tax treaties.

Desirable nontax attributes of a tax haven include qualified personnel; communications capabilities; a location preferably within a convenient time zone; a legal and regulatory environment in which, for example, property rights are protected and obligations are honored; no exchange control restrictions; political stability; and confidentiality. Exhibit. 6 displays a common structure of holding companies ( $\mathrm{HCs}$ ) in the Netherlands and Netherland Antilles (NA) used to minimize withholding (WH) taxes.

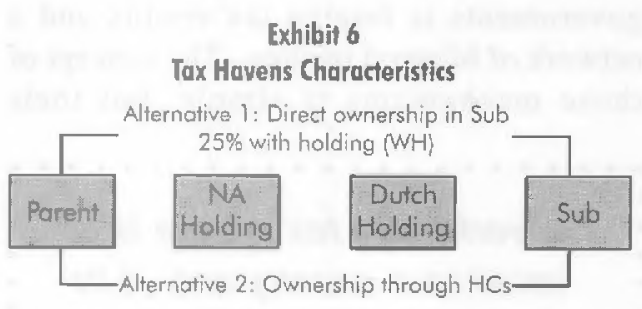

Exhibit 6 assumes that a parent company (Parent) has an operating subsidiary (Sub) abroad. Under alternative 1, Parent directly owns Sub. Because there is no tax treaty between the Parent's country and the Sub's country, a 25 percent withholding tax applies to direct distributions. Under alternative 2, Parent owns Sub through a Netherlands holding company (Dutch Holding) and a Netherlands Antilles holding company (NA Holding). Distributions from Sub to Dutch Holding are exempt under domestic Dutch law. Distributions from Dutch Holding to NA Holding are subject to low withholding rates by agreement between the Netherlands and Netherlands Antilles. ${ }^{26}$ If the Parent's country has a tax treaty with the Netherlands Antilles, distributions from NA Holding to Parent are taxed at low or zero rates as represented by the zero withholding rate shown in Exhibit 6 . In short, alternative 2 saves Parent withholding taxes of 20 percent $^{27}$ on its distributions.

Mindful that flourishing tax planning opportunities have accompanied the rapid growth of international trade and tax havens, governments have enforced a variety of anti- avoidance legislation which may be broadly categorized into the following four goups. First, required administrative consent or exchange controls have been used to restrict forming entities in, or shifting profits to, a low tax jurisdiction. Second, mechanisms that prevent tax free or deferred accumulations of profits in tax havens are often enacted. Third, to the extent profits are being shifted to tax havens by means of transfer pricing, it has already been noted that transfer pricing has been the subject of significant evaluation by many tax authorities. Fourth, steps have been taken by govemments to minimize the use of treaty networks to reduce taxes, for example, through treaty shopping.

Brazil's recently adopted worldwide tax system created the potential for a novel tax savings opportunity for Brazilian companies. The critical tax authorities underlying this opportunity include the following:

- Treaty Provision. Brazil's standard and longstanding tax treaty with Portugal, including its territory of Madeira Island, indicates that Brazil may tax foreign income upon repatriation, but not accrued foreign income ${ }^{28}$ Madeira Island is a tax haven that falls in the no or low tax category.

- The Law. As already noted, under Brazil's new worldwide tax system the income of foreign subsidiaries is taxed as accrued, not upon repatriation. ${ }^{29}$

- Normative Instruction (NI). It has also been noted that, about six months after the law was enacted, a tax pronouncement, or so-called NI, provided that authorities act contrary to the law and tax foreign income upon repatriation, and not accrued foreign income. ${ }^{30}$ Although taxpayers may act in accordance with the NI, arguably it does not supercede the law. Therefore, a case can be made for taxpayers to act at their discretion under either the law or the NI.

Consider a Brazilian corporation with a Madeira Island subsidiary. Two events are relevant to the analysis. First, income is recognized on Madeira Island through transfer pricing or other mechanisms. Second, this income is repatriated as a dividend to the Brazilian parent. Exhibit 7 summarizes the interaction among these events and the authorities cited above.

Upon the first event, income recognition on Madeira Island the treaty provision
26. Under agreement between the Netherlands and Netherlands Antilles, the withholding rate may be between 5 and 7.5 percent.

27. $20 \%=25 \%$ alternative 1 withholding tax rate - $5 \%$ alternative 2 withholding tax rate.

28. Tax treaty Aricle 7.

29. Law 9.249/95. Article 25. December 26, 1995 effective January 1, 1996.

30. Instruçāo Normativa 38. Article 2, Sectlon 1. June 28, 1996. 
31. At this writing, Brazil has tax treaties with Argentina, Austria, Belgium, Canada, the People's Republic of China, Czechoslovakia, Denmark, Ecuador, Finland, France, Germany, Hungary, India, Italy, Japan, Korea, Luxembourg, the Netherlands, Norway, the Philippines,Pontugal,Slovakia,Spain, and Sweden. Brazil is currently negotiating tax treaties with Chile, Romania, Switzerland, the United Kingoom, the United States, and Venezuela.

\section{Exhibit 7}

Madeira Island Tax Haven Use by Brazilian Companies

Event I: Income recognized by foreign subsidiary

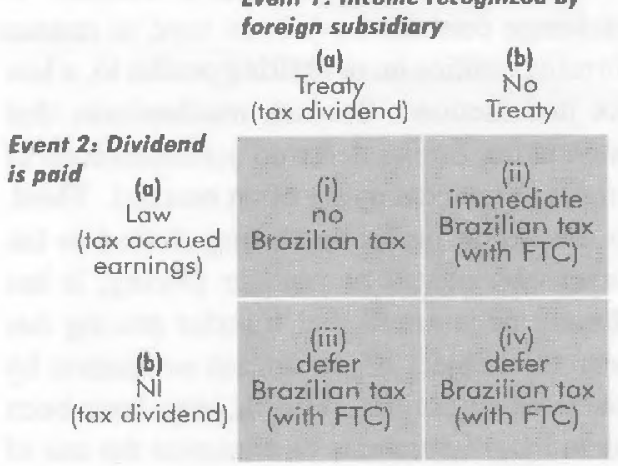

(column a) dominates domestic law, hence there is no taxable income recognized by Brazil. In addition, the income is not taxed on Madeira Island because of its zero tax rate. When, in the second event, income is repatriated to Brazil, the taxpayer minimizes taxes by choosing to act under the law (row b) which stipulates that dividends are not taxed. In short, the Brazilian parent escapes tax altogether (cell i) under this strategy.

If a subsidiary is in a country that doesn't participate in the treaty (column b) ${ }^{31}$, the Brazilian parent minimizes income taxes by choosing to operate under the NI (row b). Accordingly, Brazilian income taxes are deferred (cell iv) until earnings are repatriated. This is preferable to operate under the law (row a) and immediatly being taxed in Brazil (cell ii) as foreign income is accrued at home even if not repatriated.

At this writing, the argument is still open for the Madeira Island strategy above, albeit still subject to the success of potential government counter arguments. Nonetheless, this strategy is likely to be short lived because of its unintended outcome and transparent nature. When it ceases to be available, the use of tax havens by Brazilian companies will likely conform more readily to the use adopted by most other nations under a worldwide tax system. More specifically, to the extent Brazilian companies can recognize and retain income in tax preferred countries they will defer Brazilian income tax. However, upon repatriation, this income will be subjected to Brazilian tax with the possible relief of the foreign tax credit.

\section{CONCLUSION}

A worldwide tax system is of value to a country only if its businesses have significant international operations. Accordingly, the adoption of such a system is an indication of Brazil's increasing globalization and future expansion. At the same time, the fundamental change represented by this new system introduces a new level of complexity that creates significant challenges for governments and businesses alike. No longer do taxes apply to income just within Brazil's territory as under the former territorial tax system. Now the interaction of tax systems and rates across multiple countries must be considered. The fundamental danger this creates is the possibility of double taxation. The common response adopted by Brazil and other governments is foreign tax credits and a network of bilateral treaties. The concept of those mechanisms is simple, but their

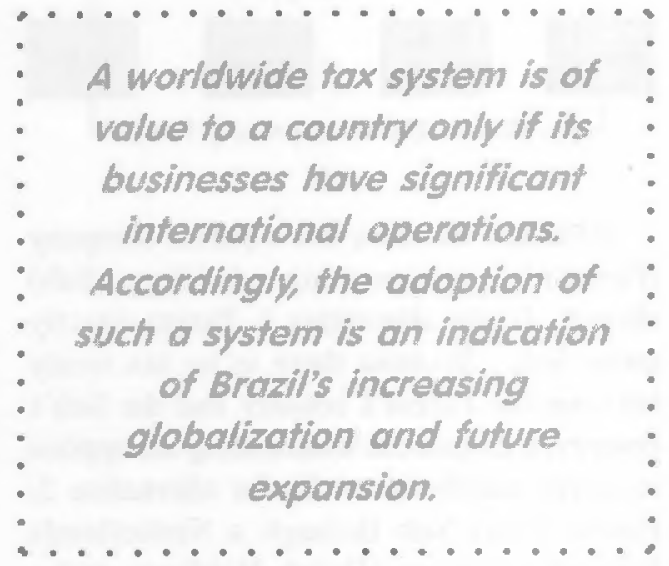

application may be fraught with difficulties. These difficulties impose administrative costs on goveruments and compliance costs on businesses. The Brazilian government intend to benefit from the experiences of other countries with long-standing worldwide systems. Similarly, Brazilian multinational companies can look to the numerous strategies and expertise already developed by nonBrazilian multinationals in their efforts to minimize global taxation. 